\title{
İstanbul'da Gerçekleştirilen Terör Saldırılarının İncelenerek Bu Destinasyonun İmajının Turistlerin Zihinlerinde Oluşturdukları Algıların Değerlendirilmesi
}

\author{
Yüksek Lisans Öğrencisi Oğuz ÇAM \\ Kastamonu Üniversitesi, Sosyal Bilimler Enstitüsü \\ oguzcam911@gmail.com \\ https://orcid.org/0000-0003-3222-3367 \\ DOI: https://doi.org/10.37847/tdtad. 827370 \\ Makale Gönderim Tarihi: 17.11.2020
}

\author{
Dr. Öğr. Üyesi Hakkı ÇILGINOĞLU \\ Kastamonu Üniversitesi, Turizm Fakültesi \\ hcilginoglu@kastamonu.edu.tr \\ https://orcid.org/0000-0002-6787-3397 \\ Makale Türü: Araştırma Makalesi \\ Makale Kabul Tarihi: 30.11.2020
}

\section{Özet}

İstanbul turizm destinasyonu çok önemli potansiyele sahiptir. Şehirde gerçekleştirilen terör saldırıları turizm talebine olumsuz etki etmektedir. Turistlerin algılarını olumsuz etkilemekte ve şehrin destinasyon imajı zarar görmektedir. İstanbul gerek nüfusu gerekse iş imkânlar1 bakımından Türkiye'de önde gelen kentler arasında yer almaktadır. Turizmden elde edilen gelirin önemli bir payı İstanbul'dan karşılanmaktadır. Terör örgütleri ve terör yandaşları ekonomiyi çökertmenin peşinde koşmaktadır. Ülke çapında elde edilen gelirlerin önemli bir bölümü turizmden karşılanmaktadır. Terör saldırıları en çok turistlerin yoğun olarak görüldüğü ve emniyet güçlerinin yoğun olarak bulunduğu yerlere gerçekleştirilmektedir. Ulusal ve küresel anlamda öneme sahip olan İstanbul ilinde meydana terör olaylarının altındaki asıl sorunların belirlenip, bu konuda yeni çözüm yollarının ortaya konulması gerekmektedir. Bu doğrultuda İstanbul kentinin destinasyon imajının turistlerin zihinlerinde bıraktıkları alg1 ve düşüncelerin neticesinde neler yaşandığı, mevcut destinasyon imajının nasıl daha iyi bir noktaya getirilebileceği hususunda bu tür bir çalışma gerçekleştirme gayretinde bulunulmaktadır. Bu anlamda yapılan ilk ve özgün çalışma olması sebebiyle turizm-terör ve benzeri alanlarda çalışma yapanlara kaynak teşkil edecektir. Ulusal platformlarda İstanbul'un daha kapsamlı bir şekilde göz önünde bulundurulması gerekmektedir. İstanbul, doğal, kültürel, beşeri ve siyasi faktörler yönünden incelendiğinde mühim bir turizm destinasyonu olduğu görülmektedir. Güvenlik önlemlerinin artırılması, insanların bilinçlendirilmesi, yaşama hakkına saygı duyulması, siyasi ilişkilerin iyileştirilmesi önemli olmaktadır. Terör olaylarının gerçekleşmeden önce kontrol altına alınması can ve mal kaybının ortaya çıkmasına engel olacaktır. Bölgeyi ziyaret eden / edecek turistlerin zihinlerinde oluşturacakları kötü ve olumsuz algıların bir nevi önüne geçilmiş olacaktır.

Anahtar Kelimeler: Terör, Alg1, Turist, Destinasyon, İstanbul.

\section{Examining the Terrorist Attacks in Istanbul and Evaluating the Perceptions Created by the Image of this Destination in the Minds of Tourists}

\begin{abstract}
Istanbul tourism destination has a very important potential. Terrorist attacks in the city negatively affect the demand for tourism. It negatively affects the perceptions of tourists and the city's destination image is damaged. Istanbul business opportunities both in terms of its population is among the leading cities in Turkey. An important share of the income obtained from tourism is met from Istanbul. Terrorist organizations and supporters of terrorism seek to collapse the economy. A significant portion of the country-wide revenues is met from tourism. Terrorist attacks are mostly carried out in places where tourists are seen and where police forces are concentrated. It is necessary to identify the main problems under the terrorist incidents in the province of Istanbul, which has national and global importance, and to find new solutions to this
\end{abstract}


issue. In this direction, efforts are made to carry out such a study on what the city of Istanbul experiences as a result of the perceptions and thoughts left in the minds of tourists and how the current destination image can be improved. As it is the first and original work done in this sense, it will constitute a resource for those working in tourism-terror and similar fields. Istanbul needs to be considered more comprehensively in national platforms. When Istanbul is examined in terms of natural, cultural, human and political factors, it is seen that it is an important tourism destination. It is important to increase security measures, raise awareness of people, respect the right to life, and improve political relations. Taking the terrorist incidents under control before they happen will prevent the loss of life and property. The bad and negative perceptions of the tourists who visit / will be in the region will be prevented in a way.

Keywords: Terror, Perception, Tourist, Destination, Istanbul.

\section{GíRiş}

Turizm için en önemli unsurlardan biri olarak insan dikkat çekmektedir. İnsanların kendilerini mutlu ve huzurlu hissetmek için güvenlik olmazsa olmaz bir olgu olmaktadır. Turizm alanında hizmet gösteren bölgelerde emniyet ve güvenlik problemleri bölge halkını ve özellikle turistleri çok olumsuz etkilemektedir. İstanbul ili, kültürel değerleri, somut kültürel miras / somut olmayan kültürel mirasları, doğal ve tarihi güzellikleri, çevresel mimarisi, çekicilikleri ile ulusal ve uluslararası alanlarda önemli bir ölçüde saygınlık kazanmıştır. Terör saldırıları bu ilde doğal, kültürel ve tarihi değerleri hedef alma, insanlara zarar verme, ekonomiyi çökertme, can ve mal kayıplarını meydana getirme, yıldırma, korkutma, bezdirme, hayal kırıklığına uğratma gibi olaylara neden olmaktadır. Bu nedenlerden dolayı İstanbul, turizm destinasyonu olarak zor zamanlar geçirmekte ve bu anlamda önemli yaralar almaktadır. İstanbul, Türkiye' de çok önemli ve saygıdeğer turizm destinasyonu imajı çizmektedir. İstanbul'da gerçekleştirilen terör olayları turizmden alınan ekonomik payı azaltmakta, ekonomiye zarar vermekte, turistlerin bu destinasyon ile ilgili oluşan algılarını olumsuz etkilemektedir. Kişiler tatil planlarını iptal etme veya mevcut destinasyonu değiştirme girişiminde bulunabilmektedir.

\section{LITERATÜR İNCELEMESI}

İstanbul ili; boğazı, adaları, tarihi yarımadası gibi hem doğal hem de kültürel özellikleri ve gelişim içerisinde olan turizm türleriyle, alternatif bir turizm varış noktası olarak pek fazla sayıda turisti bölgeye çekmektedir (İstanbul Kalkınma Ajans1, 2012: 2857).

Turizm sektörü, sosyal, çevresel, ekonomik ve siyasi olaylar gibi farklı dış ve iç etmenlere karşı oldukça hassas bir yapıya sahip olması nedeniyle; çevresel ve ekonomik kriz, terör ve savaş gibi olaylardan en hızlı ve en çok etkilenen sektörlerin başında yer almaktadır (Hacıoğlu ve Saylan, 2014). Hırsızlık, gasp, adam yaralama, ekonomik kriz, terör, savaş ve benzeri gibi yaşanan olumsuz olaylar da turizmi ve ziyaretçilerin taleplerini çok büyük oranda etkilediği görülmektedir (Polat, 2019: 1).

Destinasyon imajı, potansiyel turistlerin destinasyona dönük beklentilerinin ve algılarının bütünü biçiminde ifade edilebilir (Murphy vd., 2000; Akyurt ve Atay, 2009). Ziyaretçilerin, gidecekleri varış yerini tercih etme nedenleri arasında destinasyon imajı ilk sıralarda yer almaktadır (Kozak, 2010).

Herhangi bir destinasyonda, turistlerin maruz kaldığı hırsızlık, gasp, adam yaralama, meydana gelen iç karışıklıklar sonucunda, bölgenin güvenlik imajının zarar görmesinin yanı sıra destinasyona ait turizm taleplerinde de düşüşlerin ortaya çıkması olası bir durum olmaktadır (Seçilmiş ve Ünlüönen, 2009: 69).

Turistik destinasyonlarda turistlere yönelik gerçekleştirilen suçlar, turizm destinasyonunu olumsuz biçimde etkileyebilmekte ve turistler açısından güvenlik problemi olduğu düşünülen 
destinasyonlara istenilen ve beklenen oranlarda turist gelişlerine de engel teşkil edebilmektedir (Polat, 2019: 92).

Turistlerin konaklayacağı veya konakladığı alanlar ile alakalı algıladıkları kişisel güvenlik riskleri neticesinde kendilerini güvensiz hissetmeleri, o alanlara ilişkin güvenlik sorunu gelişmesi yaratıp, tatil yapma planlarında değişiklik yapmalarına sebebiyet verebilmektedir. Turistlerin gözünde söz konusu destinasyon hakkında negatif bir destinasyon oluşabilmektedir (Aksu vd., 2013).

Bir varış yerinde ortaya çıkan terör olayları ya da savaş, sonrasında turizm talebinin ve gelirinin düşmesi gibi turizme doğrudan etkilerinin yanı sıra, bahsedilen olayların söz konusu varış yerine yeni turistlerin çekilmesi hususunda daha çok reklam ve tanıtım harcaması, zarara uğrayan turistik altyapıların baştan inşa edilmesine yönelik harcama ve terörü en az seviyeye getirmek amacıyla daha çok güvenlik tedbiri harcaması gibi dolaylar1 etkileri de mevcut olmaktadır (Yılmaz ve Yilmaz, 2005).

Güvenlik problemleri, bölgeye seyahat gerçekleştirmeyi planlayan ya da seyahat eden turistler için sorun oluşturduğu kadar; turizm planlamacıları ve bölge içerisinde faaliyetlerini devam ettiren konaklama işletmeleri yöneticileri için de sorun oluşturmaktadır (Timothy ve Teye, 2009).

Turistler bakımından, bir bölgenin güvenli biçimde algılanması için o bölgedeki turistik talebin nasıl bir durumda olduğu çok mühim olmaktadır. Turistik talep medyada gündeme getirilen haberlerden, kişiden kişiye yayılan söylemlere kadar pek çok yönde etki göstermektedir. Güvenliğin olumsuz biçimde algılanması, şahsi güvenlik endişesi ve gelecek zamandaki seyahatleri belirleme konusunda etkili olduğunu apaçık ortaya çıkarmaktadır. Güvenlik olumlu biçimde algılanırsa, turist ziyaret ettiği destinasyondan memnun ayrılacak ve gelecek zamanlarda tekrardan ziyaret gerçekleştirme niyetinde olabilecektir (Polat, 2019: i).

Turizm sektörü, türlü güvenlik problemlerinden kolaylıkla etkilenebilmektedir. Güvenlik problemlerinin turistik talebe etki göstermesi neticesi, ulusal ya da uluslararası seyahate katılan turistlerin güvenlik algısını da yüksek oranda etkilediği görülmektedir. Dolayısı ile turistlerin memnuniyet algıları olumsuz bir biçimde etkilendiğinde, tekrar ziyaret gerçekleştirme arzuları da azalma gösterebilmektedir (Polat, 2019: ii).

Turist seyahat etmeyi arzu ettiği bölgeyle ilgili “'canına, malına, sağlı̆̆ına"' gelebilecek zararlar hususunda ortaya çıkabilecek tehdit ve riskler turistlerin karar verme sürecine etki edebilecektir (Çakmakçı, 2015).

Olumsuz vaziyetler ile karşı karşıya kalan turistler, varış yeri tercihlerini değiştirmekten ve seyahat planlarını iptal etmelerine kadar birbirinden farklı tepkiler gösterebilmektedir. Böyle durumlarda turistik alanlarda, terör saldırıları başta olmak üzere çeşitli nedenlerle ortaya çıkan 'güvensizlik ortamının ortadan kaldırılması olabildiğince önem arz etmektedir (Polat, 2019: 34$35)$.

Dünyanın rastgele bir yerine ya da turizm destinasyonuna ziyaret etme sirasinda algilanan "terör riski" turistlerin ana ihtiyaçlarından bir tanesi olan şahsi güvenlik algısına kötü yönde etki edeceğinden, turistlerin yapacağı yolculuk ve tatil planı yapma kararları da bu durumdan direkt olarak etkilenmektedir (Aymankuy vd., 2016: 966).

Turistler seyahat gerçekleştirdikleri yerlerin alışveriş alanlarında, eğlence mekânlarında ve gezdikleri doğal, tarihi ya da turistik alanlarda kısaca zamanlarını geçirdikleri bütün alanlarda kendilerini rahat ve güven içinde hissetmeyi arzu etmektedir (Seçilmiş, 2005: 15). Terör saldırıları veya benzeri yaşanan problemler tatil kararı almayı ve daha önceden yapılan planları iptal etme hususunda oldukça etkin rol oynamaktadır (WTO, 2001: 9). Turistler tatil yapma planı yaparken, ilk olarak tatilini en iyi bir şekilde ve güven ortamı içerisinde nerede geçireceği 
kararını almaktadır (Seçilmiş ve Ünlüönen, 2009: 66). Bir ülkenin 'turizm talebi”' o ülkenin turizm sektörü içerisindeki ürün ve hizmet kalitelerine, olumsuz durumda ortaya çıkan siyasi gelişmelere, can / mal güvenliğini tehdit edebilecek terör olaylarına ve varış yerlerinin imajına zarar verebilecek durumlara karşı oldukça hassas bir yapıda olmaktadır. Son zamanlarda şiddetini ve etkinliğini artıran terör olayları turizm sektörünü de olumsuz bir şekilde etkilediği için, ülke yönetimlerinin bu konularda çok mühim tedbirler alması hayati derecede önem taşımaktadır (Serçek ve Serçek, 2016: 432).

Terörü; uzun vadeli dehşet ve korku durumlarının ifade edilmesi olarak tanımlamak mümkün olmaktadır. "Terörizm", "şiddet ve tehdit kullanılarak hedef alınan kesimlerde korkuyu ve kargaşayı meydana getiren eylemler" olarak tanımlanabilmektedir. Terörizm; terörün meydana getirilmesini amaçlayan stratejileri belirtmektedir (Caşın, 2008: 102-103). Terörizm, aslında bir güvenlik sorunu olarak öne çıksa da; bu problemin beraberinde; psikolojik, sosyal, kültürel, ekonomik ve siyasi sebeplere de dayandığı görülmektedir (Polat, 2019: 64-65).

Terörizmin, turizm talebine etki alanlarının belirlenebilmesi noktasında akademisyenlerin, iki öğe üzerinde durduğu görülmektedir. Birincisi; ülke içindeki terörün şiddeti olmaktadır (terör saldırılarında yaralananların ya da ölenlerin sayılarını ifade etmektedir). İkinci ise; ülke içindeki terör saldırılarının yapıldığı sıklık olmaktadır (belirli zaman dilimlerinde belirli ülkelerde yapılan terör saldırılarının sayılarını ifade etmektedir). Terörizm, huzur dolu bir ortamın oluşturulması ve ya da muhafaza edilmesine çok büyük engel teşkil etmektedir. Teröristler cana-mala zarar vermeyi, ekonomik yönden çökertmeyi amaçlamaktadır ve turistlere yönelik yapılan saldırıların son senelerde daha da şiddetlendiği gözlenmektedir (Matilda Van Niekerk, 2015: 3-4).

Bir ülkede ortaya çıkan terörün şiddeti ve sıklığı, gezmenlerin varış yeri tercihini yapmalarını meydana getirmektedir. Terör turizm talebini oldukça olumsuz yönde etkilerken, terörün gerçekleme şiddeti ile sıklığı az olan terör saldırılarının kısa zaman diliminde olmasa bile, orta ve uzun vadelerde varış yeri seçiminde çok fazla bir etkisinin olmadığı görülmektedir (Küçükaltan, 2012: 38). Türk turizm talebi; "Sultan Ahmet Meydanı"' terör saldırılarından, "Atatürk Havalimanı", terör saldırılarından, "15 Temmuz Darbe Girişimi"' ile beraber sokaklarda yaşanan olaylardan, iç karışıklıklardan, iç çatışmalardan dolayı aşırı derece olumsuz etkilenmiş bulunmaktadır (Köşker, 2017).

Terör saldırıları ve savaş gibi güvenlik risklerinin arttı̆̆ı vaziyetlerde bu ülkelere olan turizm talebinin de azaldığı gözlemlenmektedir (Serçek ve Serçek, 2016: 436). Güvenli bir tatil anlayış1 turizmin olmazsa olmaz öğelerinden bir tanesi olmaktadır. Hiçbir gezgin para ödeyerek risk satın almak istemeyeceğinden dolayı, gezginler tarafından tatil yerini tercih etmede en başta aranılan özellik, kendilerini güven içerisinde hissedecekleri bir yer olmaktadır (Şener, 2012: 54). İnsanların güvenlik algılarını etkileyen, medyada ortaya çıkan haberler, yaşanılan olumlu ve olumsuz deneyimler, ağızdan ağza söylemler (arkadaş görüşleri) ve gidilecek olan turistik bölgenin güvenlik imajı ile kamu düzeni, turistlerin tercih seçiminde etkili olmakta ve güvenliği yeterince iyi olmayıp eksik olan riskli yerler turistler tarafından tercih edilmemektedir (Çeken, 2016: 59).

15 Temmuz 2016 senesinde gerçekleştirilen darbe kalkışmasının ve terör olaylarının Türkiye'de turizm sektörünü oldukça yoğun bir şekilde olumsuz etkilediği, Türkiye'ye seyahat gerçekleştirmeyi arzu eden yabancıların karşılarına çıkabilecek olası risklere karşı hazırlıklı olmalarının gerektiği ihtarının yapıldığı bilinmektedir (https://odatv.com/turistler-turkiyeyegelmeden-once-googleda-ne-ariyor-1306171200.html).

Seyahat etme kararlarında gidilecek ya da gidilen yerde güvenlik içinde olabilme inancı ilk aşamada etkin rol üstlendiğinden, bir turizm destinasyonunda ortaya çıacak güvenlik ile ilgili yaşanan olumsuz olaylar bu destinasyona ait turizm talebinin düşüş göstermesine neden olmaktadır (Bayhan ve Ünlüönen, 2016: 2-5). 
2016 senesinin sonlarına kadar süren terör saldırıları, Türkiye'de büyük ölçüde turist kaybının yaşanmasına sebebiyet vermiştir. Komşu ülkelerde yaşanan iç karışıklıklar ve izlenilen dış politikalar gibi etkenler de bu turist kaybını tetiklemiştir. Terör olaylarının büyük bir kesiminin çok fazla kişinin olduğu alanlarda, güvenlik güçlerinin ve turist kafilelerinin yoğunluk gösterdiği bölgelerde katliam biçiminde yapılmış olması, Türkiye'nin güvenlik imajını ciddi şekilde etkilemiş, uluslararası basında da terör saldırılarıyla zikredilmesine sebep olmuştur. $\mathrm{Bu}$ yaşanan olumsuzluklar da başka şehirlerde olduğu gibi İstanbul iline gelen turistlerin sayısında da yüksek oranlarda azalmaya neden olmuştur (Demirci, 2018: 35). Türkiye'de bilhassa son yıllarda yoğunlaşan terör olaylarının artış gösterdiği ve bu durumların kitlesel ölümlere kadar dayanmış olduğu görülmektedir. Komşu ülkelerde yaşanan ekonomik krizler, sıcak savaş halinin devam etmesi ve bu sebepler ile ülkemize 2016 senesi başlarına değin tam dört milyondan fazla mültecinin gelmesi, hatta gerçekleştirilen uluslararası anlaşmalar ile bu sayıların önemli ölçülerde artacak olması, bu durumların da en başta sağlık ve güvenlik olmak üzere birçok problemi de beraberinde getirecek olması düşünülmektedir (Çılgınoğlu, 2018: 240).

\section{METOT}

\section{Araștırmanın Problemi}

Turizm sektörü, bir ülkenin ekonomisi içerisindeki en önemli gelir kaynaklarından bir tanesi olmaktadır. Ulusal ve uluslararası turizm stratejileri, planları, programları, hedefleri ülkelerin turizm potansiyelinin artırılması için önemlilik arz etmektedir. Turizmin önündeki en büyük engel teşkil edici unsurlardan bir tanesi terör ve terörizmdir. Terör saldırıları bir şehrin ve ülkenin imajını aşırı yönde olumsuz etkilediği tartılmaz bir gerçek olmaktadır. İstanbul'da meydana gelen terör olayları, eylemler insanları canından bezdirmekte ve hatta insanların canına mal olabilmektedir. Turizm konusunda konu ele alındığında terörün turizm gelirlerinde azalmalara neden olduğu aşikâr bir durum olmaktadır. Terör olaylarından dolayı turistlerin bir bölgeyi tercih etme oranı azalmakta, bu bölgelere karşı turistler önyargı ve olumsuz bir alg1 besleyebilmektedirler. Bu sorunların üstesinden gelebilmek için siyasi, ekonomik, psikolojik, çevresel, sosyal sorunlara eğilmek gerekmektedir. Terör ve terörizm, mevcut olan söz konusu sorunlar ışı̆̆ında baş göstermektedir.

\section{Araştırmanın Amacı}

İstanbul, hem Türkiye'de hem de dünyada çok saygı değer bir konuma sahip olmaktadır. Şehirde gerçekleştirilen terör olayları, bölge halkına ve turistlere aşırı bir derecede zarar vermektedir. Kentin destinasyon imajını sekteye uğratmaktadır. Gelen turistlerin şehre bakış açıları olumsuz bir hal almaktadır. Terör grupları, yaptıkları saldırılarda insanoğlunu maddi ve manevi her türlü, cana ve mala kastedebilecek kadar sınırsız kötü davranışlar sergilemekte, ekonomik tahribatı ve insan tahribatını amaç edinmektedir. Korkutmak, bezdirmek, gözdağı vermek, psikolojik baskı yapmak, tehdit etmek yoluyla insanları hedef almaktadır. Ulusal ve küresel anlamda öneme sahip olan İstanbul ilinde meydana terör olaylarının altındaki asıl sorunların belirlenip, bu konuda yeni çözüm yollarının ortaya konulması gerekmektedir. Bu doğrultuda İstanbul kentinin destinasyon imajının turistlerin zihinlerinde biraktıkları algı ve düşüncelerin neticesinde neler yaşandığı, mevcut destinasyon imajının nasıl etkilenebileceği hususunda bu tür bir çalışma gerçekleştirme gayreti içerisinde bulunulmuştur.

\section{Araştırmanın Önemi}

Çalışma, bu anlamda yapılan ilk ve özgün çalışma olması sebebiyle turizm-terör ve benzeri alanlarda çalışma yapanlara kaynak teşkil edecektir. Ulusal platformlarda İstanbul'un daha kapsamlı bir şekilde göz önünde bulundurulması gerekmektedir. İstanbul, doğal, kültürel, beşeri ve siyasi faktörler yönünden incelendiğinde mühim bir turizm destinasyonu olduğu görülmektedir. Güvenlik önlemlerinin artırılması, insanların bilinçlendirilmesi, yaşama hakkına 
saygı duyulması, siyasi ilişkilerin iyileştirilmesi önemli olmaktadır. Terör olaylarının gerçekleşmeden önce kontrol altına alınması, can ve mal kaybının ortaya çıkmasına engel olacaktır. Bölgeyi ziyaret eden turistlerin zihinlerinde oluşturacakları kötü ve olumsuz algıların bir nevi önüne geçilmiş olacaktır.

\section{Araştırmanın Yöntemi}

$\mathrm{Bu}$ araştırmanın yöntemi, nitel araştırma yöntemidir. $\mathrm{Bu}$ yöntem çerçevesinde söz konusu araştırma doküman analizi tekniğiyle değerlendirilmiştir.

\section{Araştırmanın Veri Toplama Aracı ve Analizi}

$\mathrm{Bu}$ çalışma kapsamında doküman analizi yapılmıştır. Veri toplama aracı olarak internet sayfalarından, gazete yazılarından, kitaplardan makalelerden, tezlerden, konferans bildirilerinden faydalanılmaya çalışılmıştır. Turistlerin (iç turist / dış turistlerin) duyguları, düşünceleri, algıları ayrıntılı bir biçimde irdelenmeye çalışılmıştır.

\section{BULGULAR}

Tablo 1. Bulgular Tablosu

\begin{tabular}{|c|c|c|}
\hline Tarih & Yer & Olay \\
\hline 10.12.2016 & Beşiktaş & $\begin{array}{l}\text { Vodafone Stadı yanında meydana gelen terör saldırısında; } \\
\text { 150'nin üstünde kiși yaralanmıș, } 44 \text { kiși ise hayatını kaybetmiștir. }\end{array}$ \\
\hline 28.06.2016 & Bakırköy & $\begin{array}{l}\text { Atatürk Havalimanı dış hatlar terminalinde meydana gelen terör } \\
\text { saldırısı neticesinde; } 147 \text { kişi yaralanmış, } 36 \text { kişi ise hayatını } \\
\text { kaybetmiştir. }\end{array}$ \\
\hline 07.06 .2016 & Fatih & $\begin{array}{l}\text { Vezneciler'de meydana gelen terör saldırıs neticesi; } 36 \text { kişi } \\
\text { yaralanmıș, } 12 \text { kiși ise hayatını kaybetmiștir. }\end{array}$ \\
\hline 12.05.2016 & Sancaktepe & $\begin{array}{l}\text { Samandıra kışlası yakınlarında 3'ü sivil, 5'i asker olmak üzere } \\
\text { tam } 8 \text { kişi yaralanmıştır. }\end{array}$ \\
\hline 19.03.2016 & Beyoğlu & $\begin{array}{l}\text { İstiklal Caddesinde meydana gelen terör saldırısı neticesi; } 36 \text { kişi } \\
\text { yaralanmıs, } 5 \text { kiși ise hayatııı kaybetmiştir. }\end{array}$ \\
\hline 12.01.2016 & Fatih & $\begin{array}{l}\text { Sultanahmet Meydanı'nda yapılan terör saldırısında } 14 \text { kişi } \\
\text { yaralanmış, } 13 \text { kişi ise hayatını kaybetmiștir. }\end{array}$ \\
\hline 10.08.2015 & Fatih & $\begin{array}{l}\text { Fatih Polis Merkezi’ne yönelik yapılan terör saldırısında } 10 \text { kişi } \\
\text { yaralanmış, } 1 \text { polis müdürü de hayatını kaybetmiştir. }\end{array}$ \\
\hline 26.07.2015 & Sultangazi & $\begin{array}{l}\text { Meydana gelen silahlı saldırı neticesinde } 1 \text { polis memuru hayatını } \\
\text { kaybetmiştir. }\end{array}$ \\
\hline 06.01 .2015 & Fatih & $\begin{array}{l}\text { Sultanahmet'te bulunan Turizm Şube Müdürlüğü’ne yönelik } \\
\text { gerçekleştirilen saldırıda } 1 \text { kişi yaralanmış, } 1 \text { polis memuru ise } \\
\text { hayatını kaybetmiştir. }\end{array}$ \\
\hline 11.09.2012 & Sultangazi & $\begin{array}{l}\text { Gazi Polis Merkezi'ne yönelik gerçekleştirilen saldırıda } 7 \text { kişi } \\
\text { yaralanmış, } 1 \text { polis memuru ise hayatını kaybetmiştir. }\end{array}$ \\
\hline 31.10 .2010 & Beyoğlu & $\begin{array}{l}\text { Taksim Meydanı'nda bulunan polis } \\
\text { gerçekleştirilen intihar saldırısı neticesinde } 32 \text { kişi yaralana yönelik } \\
\text { giştır. }\end{array}$ \\
\hline 27.07.2008 & Güngören & $\begin{array}{l}\text { İki bombalı saldırı sonucunda } 154 \text { kişi yaralanmış, } 18 \text { kişi ise } \\
\text { hayatını kaybetmiștir. }\end{array}$ \\
\hline 10.06 .2007 & Bakırköy & Meydana gelen patlama sonrasında 31 kiși yaralanmıștır. \\
\hline 20.11.2003 & Beyoğlu & $\begin{array}{l}\text { İngiliz Başkonsolosluğu'na yönelik bomba yüklü araçlarla } \\
\text { gerçekleştirilen saldırı neticesinde } 700 \text { 'ü aşkın kişi yaralanmış, } 51 \\
\text { kişi ise hayatını kaybetmiştir. }\end{array}$ \\
\hline 20.11 .2003 & Şişli & $\begin{array}{l}\text { HSBC Bank Genel Müdürlüğü’ne yönelik gerçekleştirilen saldırı } \\
\text { neticesinde, } 11 \text { kişi hayatını kaybetmiştir. }\end{array}$ \\
\hline 15.11 .2003 & $\begin{array}{l}\text { Beyoğlu ve } \\
\text { Şişli }\end{array}$ & $\begin{array}{l}\text { İki ayrı sinagoga eş zamanlı olarak yapılan saldırı neticesinde } 262 \\
\text { kişi yaralanmış, } 25 \text { kişi ise hayatını kaybetmiştir. }\end{array}$ \\
\hline
\end{tabular}

Kaynak: Demirci, 2018: 30-31; Alan, 2016: 79. 
10 Aralık 2016 tarihinde İstanbul Vodafone Arena Stadı'nın yakınlarında terör saldırısı gerçekleştirilmiştir. Bu saldırı neticesinde 44 kişi yaşamını yitirmiştir. Reuters'a konuşan ve patlama esnasında olay yerinin yakınlarında olan bir görgü tanığı, "Cehennem gibiydi. Alevler gökyüzüne kadar uzandı" demiştir. Doğan Haber Ajansı (DHA) bu patlamanın, Anadolu Yakası'nda Üsküdar ve Beylerbeyi ile Avrupa Yakası'nda Beşiktaş, Taksim, Kabataş ve Nişantaşı tarafindan duyulduğunu belirtmektedir (https://www.bbc.com/turkce/haberler-turkiye38278551). İstanbul Vodafone Arena Stadı'nda gerçekleştirilen terör olayları sonrasında milli yas ilan edilmiş, internet ve sosyal medya gibi uygulamalar yavaşlatılmıştır. Terör saldırıları İstanbul destinasyonunun imajını olumsuz etkilemektedir. Özellikle turistlerin fazlaca yoğunluk gösterdiği spor müsabakalarının yapıldığı merkezler ve yakınlarına gerçekleştirilen hain saldırılar, ulusal ve uluslararası kamuoyunda çok büyük yankı bulmasına sebep olmuştur. İnsanların huzur ve dirliğini bozmak, gerçekleştirilen faaliyet ve etkinliklerin azalmasını sağlamak, korku ve dehşet saçarak onları yıldırmaya çalışmak terör olaylarını gerçekleştiren kimselerin izledikleri yollar olmaktadır. Bu terör olaylarının turistlerin yoğun olduğu yerlerde yapılmasının temel sebepleri içerisinde ülkelerin diğer ülkeler ile olan ilişkilerinin zedelemek, ekonomiyi baltalamak, bir destinasyona/ülkeye olan ziyaretçi sayılarını azaltmak, kötü, olumsuz bir imaj ve izlenim oluşturmak sayllabilmektedir.

Atatürk Havalimanı'nda gerçekleştirilen terör saldırısında 100'ü aşkın kişi yaralanmış, 36 kişi hayatını kaybetmiştir. Eşi ile beraber alanda bulunan Güney Afrikalı Paul Roos, "Dış hatlara geldiğimizde bir kişinin rastgele ateş ettiğini gördüm. Önüne gelene ateş ediyordu. Siyahlar giymişti. Yüzünde ise maske yoktu, 50 metre uzağındaydım" dedi. Silah seslerinden sonra kontuarın arkasına saklandıklarını anlatan Roos, şöyle devam etti: "Sonra ayağa kalkıp izlemeye başladım. Art arda iki patlama meydana geldi. O sırada ateş etmeyi kesmişti. Sonra geri döndü ve bize doğru gelmeye başladı. Silahını ceketine saklamışı. Kendisini durdurmaya gelen olup olmadı̆̆ını anlamak için endişeyle çevresine bakındl, ardından yürüyen merdivenle aşağı indi. Bir süre daha silah sesi duyduk, sonra bir patlama daha, sonra ses kesildi" demiştir. Facebook, Atatürk Havalimanı'nda gerçekleştirilen terör olaylarından sonra 'Güvenlik Durumu Kontrolü' dugulamasını devreye sokmuştur. (https://tr.sputniknews.com/turkiye/201606281023616914-ataturk-havalimani-patlama-silahsesi/).

İstanbul Cumhuriyet Başsavcılığı Basın Suçları Bürosu'nun, Ortaköy'de bir gece kulübünde 39 kişinin yaşamını yitirdiği saldırı sonrasında sosyal medya üzerinde "oh olsun..." tarzı paylaşımlarda bulunanlara dair "halkı kin ve düşmanlığa tahrik veya aşağılama" suçlarından resmi olarak soruşturma başlattığı öğrenildi. Savcıllğın bu mevzuyla alakalı olarak İstanbul Emniyet Müdürlüğü Güvenlik Şube Müdürlügü’ne talimat verdiği ortaya çıkmıştır. Savcılığın vermiş olduğu bu talimat üzerine gerçekleştirilecek çalışma neticesinde belirlenecek paylaşımların sahipleri bulunmaya çalışılacaktır. Bir kısmı takma isim veya sahte isimler ile oluşturulan hesaplardan gerçekleştirilen bu paylaşımlar ile alakalı şüphelileri tespit etmek ve bulmak için çeşitli taramalar yapılacaktır. Aynı konuyla ilişkili olarak Ankara Cumhuriyet Başsavcılığı da gerçekleştirilen saldırı sonrasında sosyal medyadaki paylaşımlar hakkında "halkı kin ve düşmanliğa tahrik veya aşağılama", "terör örgütü propagandası yapmak" ve "Türk milletini, Türkiye Cumhuriyeti devletini, devletin kurum ve organlarını aşağılama" suçlarından dolayı resmi olarak soruşturma başlatmış bulunmaktadır (https://www.kamupersoneli.net/gundem/istanbul-reina-teror-saldirisini-oven-paylasimlarasorusturma-acildi-h20234.html).

Dijital ve sosyal medya artık yediden yetmiş yediye çoğu kişi tarafından aktif kullanılmaktadır. İnsanlar zamanının birçoğunu bu platformlarda geçirmektedirler. İnsanları galeyana getiren, aşağılayan, küçük düşüren, küçümseyen, kin ve düşmanlıkla dolu bir ruh haline büründüren, olumsuz bir alg1 oluşturup insanlar üzerinde kötü bir izlenim bırakan sosyal medyadaki paylaşımlara yönelik çok ciddi yaptırımlar, soruşturmalar gerçekleştirilmektedir. Terörü 
destekleyenler ve terör örgütlerinin ilk olarak asıl gayeleri aslında insanları bezdirmek, korkutmak ve yıldırmaktır. Sosyal olarak birlik ve bütünlügün ortadan kaldırılmasıdır. Bir ülkenin topraklarını ve insanlarını parça parça edip, zayıflatıp sonra da amaçlarına ulaşmayı hedeflemektedirler. İnsanlar sosyal medyada dolaşan birtakım bilgilere karşı dikkatli olmalıdır.

Giovanna Lanzavecchia adlı İtalyan bir turistin İstiklal Caddesi'nde 4 kişinin yaşamını yitirdiği saldırı ile alakalı sosyal medya hesabı üzerinden İngilizce bir haberi "Taksim Meydanı. Çok klas bir şey (Piazza Taksim. Che figata)" sözleri ile paylaşmasının ardından polis ekipleri ilgili kişiyi arama çalışması başlatmıştır. İtalyan turistin daha önceki zamanlarda sosyal medya hesapları üzerinde PKK, YPG ve YPJ'yi öven Kürtçe, Arapça, İtalyanca, İngilizce sayfalardan paylaşımlar gerçekleştirdiği ve ağır silahlar ile çekilmiş resimlerinin belirlenmesi üzerine polis ekipleri harekete geçmiştir. Polis ekipleri, İtalyan turisti Fatih’te kaldığı otel işletmesinde terör örgütü propagandası gerçekleştirme suçundan gözaltına almıştır. Gözaltına alınan İtalyan turist Giovanna Lanzavecchia, emniyette yapılan işlemlerin ardından adliyeye sevk edilmiştir. Mahkemede vermiş olduğu ifadede sosyal medya hesabının kendisinin olduğunu kabul etmiş, yaptığı paylaşımların ise suç olduğunu bilmediğini ifade etmiştir. İtalyan turistin adliyedeki yapılacak işlemlerin sonrasında İstanbul İl Göç İdaresi Müdürlüğ̈̈'ne götürülerek sınır dışı edileceği öğrenilmiştir (https://www.sabah.com.tr/gundem/2016/03/21/teror-propagandasiyapan-turist-sinir-disi-edilecek-1458598415).

Güvenlik unsuru; turizm destinasyonu denilince akıllara ilk gelen olgulardan bir tanesi olmaktadır. İster yeri turistler olsun, isterse yabancı turistler olsun terör olayları karşısında her şekil ve surette halkı düşmanlığa yöneltme, küçük görme, alay etme gibi sosyal medya alanlarından paylaşım gerçekleştirme suç kapsamına girmektedir. Türkiye genelinde ve özellikle kalabalık nüfusu ve turistlerin yoğun olarak ziyaret gerçekleştirmesi sebebiyle İstanbul ilinde bu tür durumlara çok dikkat edilmektedir.

Ocak 2015'te, İstanbul Sultanahmet'te bir IŞi̇D militanı Turizm Şube Müdürlügü'nün önünde elindeki el bombalarını patlatmış, bir polis memuru yaralanmış, bir polis memuru ise hayatını kaybetmiştir (https://www.bbc.com/turkce/haberler/2015/01/150106_sultanahmet_bomba).

İstanbul'un en gözde mekânlarından birisi olan Sultanahmet'te düzenlenen saldırılarda doğrudan turizm ve turistlerin hedef alındığını dile getirmek mümkün olmaktadır. Turistler sonraki zamanlarda destinasyon seçiminde daha temkinli davranacak ve terör saldırılarının gerçekleştiği destinasyonlara/ülkelere karşı olumsuz bir karar verme sürecine gireceklerdir. Güvenlik algısı turistleri derinden etkilemektedir.

19 Mart 2016 tarihinde İstiklal Caddesi'nde meydana gelen terör saldırısı neticesi; 36 kişi yaralanmış, 5 kişi ise hayatını kaybetmiştir. Olaya tanık olanların ifadelerine göre ise, canlı bombanın turist grubunun yanından geçerken bombayı infilak ettirdiğini söylemiştir. İstiklal Caddesi'nde gerçekleşen patlama anını iki görgü tanığı anlatmıştır. Birinci görgü tanığı, İstiklal Caddesi'nde yürüdügü esnada arkasında patlama sesi duyduğunu ve yaralılar gördügüunü belirtmiştir. İkinci görgü tanığı ise ölü ve yararlıların bulunduğunu ve çığlık seslerinin duyulduğunu belirterek gözyaşlarına boğulmuştur (http://www.diyarbakirsoz.com/gundem/sondakika-istanbul-istiklal-caddesi-patlamasinda-olu-ve-yaralilarin-isimleri-aciklandi-mi-149588). İstanbul'un en işlek ve en kalabalık caddelerinden olan İstiklal Caddesi'nde gerçekleşen terör saldırıları, psikolojik, ekonomik ve sosyal açlardan insanları zor duruma sokmuştur. Kişilerin, sosyal medya üzerinde 'Terörü lanetliyoruz', 'Teröre hayır' 'Terörü kinıyoruz', ve 'Teröre karşı el ele" gibi paylaşımlarda bulundukları göze çarpmaktadır. Bazı zamanlarda artık terör insanlara öyle bir korku salmıştı ki, insanlar artık kalabalık ortamlara bile girmekten korkar duruma gelmişlerdi.

31 Ekim 2010 tarihinde Taksim Meydanı'nda düzenlenen intihar saldırısında 15 tanesi polis olmak üzere toplam 32 kişi yaralanmış ve 23 kişi de ayakta tedavi edilerek taburcu edilmiştir. Son 11 senede Taksim Meydanı'nda emniyet güçlerine karşı yapılan üçüncü canlı bomba 
saldırısı olmuştur. Diğerleri ise şu şekilde gerçekleşmiştir: 27.03.1999 tarihinde Taksim Meydanı'nda Çevik Kuvvet Şube Müdürlüğüne bağlı otobüslerle bir panzerin beklediği alanda meydana gelen terör saldırısında, canlı bombalı saldırgan üzerindeki bombayı patlatmıştır. Gerçekleşen saldırıda 3 tanesi polis olmak üzere toplam 10 kişi yaralanmıştır. Diğer bir canlı bomba saldırısı ise 10.09.2001 tarihinde Gümüşsuyu Çevik Kuvvet bekleme noktasına yönelik gerçekleştirilmiştir. Bu terör saldırısında 13'ü polis memuru olmak üzere toplam 20 kişi yaralanmış, 2 polis memuru ise yaşamını yitirmiştir (https://www.iha.com.tr/haber-taksimdepatlama-144222/).

Emniyet güçlerine yönelik yapılan terör saldırıları devletin otoritesini zayıflatmayı, iç karışıklıkları ve savaşları ortaya çıkarmayı amaç edinmektedir. Terör örgütlerinin gerçekleştirdikleri terör saldırılarının en çok turistlerin yoğunluk gösterdikleri ve emniyet güçlerinin bulunduğu yerlere yapıldığı göze çarpmaktadır. Bir ülkenin en büyük gelir kaynaklarından birini turizm karşılamaktadır. Bu anlamda turizme darbe vurmak, önemli olan gelirin elde edilememesine sebep olacaktır. Gerçekleştirilen bazı terör saldırıları neticesinde yayın yasağı koyma, internette, sosyal medyalarda erişimin yavaşlatılması ve benzeri olaylarının yaşandığı görülmektedir. Bu çok doğru bir karar olmaktadır. Çünkü ortaya çıkan bütün durumları, millete ve devlete karşı kullanıp olayları çarpıtarak insanları kandırmayı isteyen, toplumun birlik ve bütünlügüne zarar vermeyi arzulayan, insanları kışkırtan, terörü ve terör örgütlerini destekleyen şahıslara karşı alınan bu tedbirler hayati önem taşımaktadır.

27.07.2008 tarihinde İstanbul Güngören'de art ardına iki bombanın infilak etmesi neticesi; 154 kişi yaralanmış ve 5 tanesi çocuk olmak üzere toplam 18 kişi yaşamını yitirmiştir. Bu gerçekleştirilen terör $\quad$ saldırısını (https://www.hurriyet.com.tr/gundem/turkiyenin-en-kanli-teror-saldirisi-30282825 ).

Terörün şiddeti ne kadar fazla olursa o kadar çok ölen ve yararlananlar olmaktadır. İnsanlar terörü ve terörü destekleyenleri lanetlemektedirler. Terör saldırıları bir şehrin sosyal ve çevresel değerlerine zarar vermekte, geriye sadece acı ve gözyaşı bırakmaktadır.

15.11.2003 tarihinde Neve Şalom Sinagogu ve Bet İsrael Sinagogu'na düzenlenen bombalı araçlı saldırı neticesinde 27 kişi hayatını kaybetmiştir. Bomba yüklü araçlar ile yapılan eylemlerde, eylemleri gerçekleştiren kişiler de hayatlarını kaybetmiştir. Patlamaların yaşandığ 1 sinagoglarda ve civarlarında büyük çaplı hasarlar meydana gelirken, en az 300 kişi de yaralanmıştır (https://www.hurriyet.com.tr/gundem/turkiyenin-en-kanli-teror-saldirisi30282825).

Terörist eylemlerin bazı zamanlarda dini inanışlara yönelik olarak gerçekleştiği görülmektedir. İnanç turizmine katılan turistler bu durumdan oldukça kötü etkilenmekte ve zarar görmektedir. Cami, mescit, kilise, sinagog, katedral, havra hiçbir şey tanımayıp talan edilen yapıların olduğunu görmek, gerek halk tarafindan gerekse turistler tarafından üzücü bir durum olmaktadır. O anki ruh halini atlatamayıp, o durumun etkisinde kalan insanlar psikologlar tarafindan eğitim görmektedir.

Sinagogları hedef alan saldırılardan tam beş gün sonrasında, 20.11.2003 tarihinde yine bombalı araçlar ile iki eylem gerçekleştirilmiştir. 20 Kasımdaki bombalı araçlı terör saldırısının asıl hedefi İstanbul şehrindeki İngiliz Konsolosluğu ve HSBC Bankası'nın genel merkezi olmuştur. Gerçekleştirilen saldırı sonrasında 450'yi aşkın kişi yaralanmış, 30 kişi ise hayatını kaybetmiştir. $\mathrm{Bu}$ terör saldırısı El-Kaide tarafindan üstlenilmiştir (https://www.hurriyet.com.tr/gundem/turkiyenin-en-kanli-teror-saldirisi-30282825). Ülkelerin konsolosluklarını hedef alan terör örgütleri ülkeler arasında problemlerin yaşanmasını, siyasi ilişkilerin kötüleşmesini ve ilişkilerin kopma noktasına gelmesini, ülkeler arası ticaretin (ithalatihracat vb.) durmasını amaçlamaktadır. 
13.03.1999 tarihinde Kadıköy ilçesindeki Mavi Çarşı'ya yönelik gerçekleștirilen molotofkokteylli terör saldırısında 13 kişi hayatını kaybetmiştir. Terör saldırısının PKK'lı olan 3 sanığı müebbet hapis cezasına çarptırılmıştır (https://www.hurriyet.com.tr/gundem/turkiyeninen-kanli-teror-saldirisi-30282825). Kadıköy, İstanbul'un en işlek ilçelerinden bir tanesi olmaktadır. Molotof kokteylli terör eylemlerinde bulanan teröristler birçok insanın hayatına kastetmiştir. İç kargaşa ve karışıklık oluşturan bu olaylar çerçevesinde doğal ve çevresel doku da zarar görmüştür.

Kanlı 1 Mayıs (01.05.1977): İşçi Bayramını kutlamak için çeşitli şehirlerden İstanbul Kentine gelen yaklaşık olarak 500.000 kişinin doldurduğu Taksim Meydanı'nda o dönemin DİSK başkanı Kemal Türkler konuşmasının sonuna geldiğinde etraftan silah sesleri gelmeye başlamıştır. Meydana gelen terör saldırısında 136 kişi yaralanmış, 34 kişi ise hayatını kaybetmiştir

(https://www.hurriyet.com.tr/gundem/turkiyenin-en-kanli-teror-saldirisi30282825).

1 Mayıs 1977 tarihinde İstanbul' da gerçekleşen terör saldırısında pek çok kişi yaralanmış ve yaşamını yitirmiştir. 1 Mayıs'ın böyle terör saldırılarıyla geçmesi de kanlı 1 Mayıs olarak anılmasına sebebiyet vermiştir. Çeşitli şehirlerden gelen 500.000 kişinin hedef alındığ 1 terör olayında daha geniş kitlelerin tahrip edilmesi, yıkıcı etkilerin daha fazla alanda tesir göstermesi amaçlanmiştır.

\section{TARTIŞMA, SONUÇ VE ÖNERILER}

Türkiye' de turizm denince akıllara ilk gelen şehirler arasında İstanbul yer almaktadır. Sahip olduğu doğal ve kültürel miraslar, hizmet kuruluşları ve ulaşım olanakları bakımından çok önemli bir potansiyele sahip olmakta, bölge, ülke ve dünya açısından önemli bir turizm destinasyonu merkezi olma niteliğini üstlenmektedir. Zaman zaman kentte meydana gelen terör olayları yerel halkı ve turistleri derinden etkilemektedir. Turistlerin söz konusu destinasyon ile ilgili algıları olumsuz etkilenmekte, tatil yapma planlarını iptal etme / ileri bir tarihe erteleme veya destinasyon tercihlerini değiştirme hususunda da kişisel güvenlik algıları etkili olabilmektedir. Bundan dolayı İstanbul'un destinasyon imajı kötü etkilenmekte ve turistler üzerinde kötü bir izlenim bırakmaktadır.

İstanbul ilinde gerçekleştirilen terör saldırıları ile ilgili sosyal medya üzerinden özellikle insanların algılarına olumsuz etki yapacak, halkı kin, nefret ve düşmanlığa sevk edecek, toplumsal ve dini değerlere zarar verecek, küçümseyici, alay edici paylaşımlarda bulunan insanlar tespit edilmiştir. Emniyet güçleri tarafından olaylar derhal kontrol altına alınıp, gereği en iyi şekilde yerine getirilmiştir. Toplumsal olaylarda dijital ve sosyal medya aktif bir role sahip olmaktadır. İnsanlar en kısa zaman dilimi içerisinde birbiri ile iletişim kurabilmektedir. Turizm ve terör ilişkisi, turizm faaliyetleri ve turistler açısından önem arz etmektedir. Şöyle ki; can ve mal güvenliğinin olmadığ 1 veya eksik olduğu yerlere kimse seyahat gerçekleştirmek istememekte, ilgili alanlarda hiçbir turizm etkinliği ve aktivitesi gerçekleştirilememektedir. Meydana gelen bazı terör olaylarından sonra yayın yasağı koyma (fotoğraf, video, bilgi paylaşımının yasaklanması) ve internet yavaşlatma gibi güvenlik amaçlı önlemler alınabilmektedir. 15.07.2016 tarihinde Türkiye'ye darbe teşebbüsünde bulunulmuştur. Birçok açıdan bu olay devletin ve milletin zarar görmesine sebep olmuştur. Türkiye'ye olan turizm talebi de olumsuz yönde etkilenmiştir. Çıkan olaylardan sonra pek çok kişi hayatını kaybetmiştir.

Atatürk Havalimanı, Sabiha Gökçen Havaalanı, Vezneciler, İstiklal Caddesi, Güngören, Beyoğlu, Şişli, Bakırköy, Sancaktepe, Beşiktaş, Fatih gibi yerlerde gerçekleşen terör saldırılarının çoğunlukla turist kafilelerini veya güvenlik güçlerini hedef aldığı görülmektedir. Türkiye'ye darbe teşebbüsünün gerçekleştirilmek istenmesinden sonrasında, İngiltere gibi bazı ülkeler Türkiye'ye seyahat gerçekleştirmenin riskli olduğunu ve her şeye hazırlıklı olmaları konusunda uyarıda bulundukları bilgilerine ulaşılabilmektedir. Kişilerin, sosyal medya üzerinde 
'Terörü lanetliyoruz", 'Teröre hayır" 'Terörü kınıyoruz', ve 'Teröre karşı el ele" gibi paylaşımlarda bulundukları göze çarpmaktadır. Bazı zamanlarda artık terör insanlara öyle bir korku salmıştı ki, insanlar kalabalık ortamlara bile girmekten korkar duruma gelmişlerdi. İstanbul'da gerçekleşen terör olayları, turistlerin gözündeki kent imajının kötü etkilenmesine ve zedelenmesine neden olmaktadır. Sosyal medya kanalları aracılığı ile asılsız, yanlış haber paylaşılabilmektedir. Terör saldırılarının asıl gayeleri arasında; ekonomik olarak çökertmek, psikolojik ve toplumsal olarak yıpratmak, cana ve mala kastetmek, yıldırmak, korkutmak, dehşet saçmak, insanların akıllarını yıkamak, dini ve sosyal değerlere zarar vermek sayılabilmektedir. Terör olaylarının yaşandığı hiçbir yerde turizm etkinlikleri ve aktivitelerinden söz etmek mümkün olmamaktadır. Turistler öncelikle gideceği ülkenin/destinasyonun yaşam kalitesini, yaşam tarzını, güvenliğini, işlenen suç oranlarını, turizm imkânlarını, ulaşımını, toplum kurallarını, gelenek ve göreneği ile ilgili davranışları araştırmaktadır. Turistlere yönelik işlenen suçlar (terör olayları, taciz, tecavüz, yaralama, kapkaç, hırsızlık, fiziksel şiddet, psikolojik bask1, alay etme, küçük düşürme, küçümseme vb.) turizm talebinin azalmasına neden olmaktadır. Turistler eğer kendilerini güvende hissetmeyip, kişisel güvenliklerini riske atacak bir durum sezerler ise; ya tatil kararlarını iptal edebilirler ya da tatil yeri tercihlerini değiştirip başka turizm destinasyonlarını tercih edebilirler. Türkiye, ekonomik gelirlerinin önemli bölümünü turizm gelirlerinden elde etmektedir. İstanbul'da Türkiye açısından değerlendirildiğinde turizmde en önemli destinasyon kentleri arasında gelmektedir. Bu şehre gerçekleştirilen terör olayları, turizm faaliyetlerini sekteye uğratmaktadır. Turistlerin gözünden bu şehrin imajının kötü etkilendiğini söylemek yerinde olmaktadır. Terör konusunda ülkeler kendi aralarında daima yardımlaşma ve dayanışma içerisinde olmaktadır. Birbirlerine taziye mesajları göndermektedir. Ülkelerin terör olayları konusunda aldığı tedbirler, uyguladığ stratejiler, acil durumlarda yapılması gereken önemli talimatlar terörün şiddetini azaltıcı önlemler arasında yer almaktadır. Siyasi anlaşmazlıklar ve ülkelerde gerçekleşen iç savaşlar, çatışmalar terör olaylarının başka ülkelere de sirayet etmesine sebep olabilmektedir.

- İnsanların kalabalık olduğu alanlarda bulunan emniyet güçlerinin sayısı artırılmalıdır.

- İnsanlar internette, özellikle sosyal medyada gördüğü her şeye inanmamalıdır.

- Kişiler, terör konusunda bilinçlendirilmelidir (yapılan uyarılar dikkate alınmalı, şüpheli kişi ve paketlerden uzak durulmal, gerekli görüldüğ̈̈ takdirde hiç vakit kaybetmeden güvenlik güçlerine haber verilmelidir).

- Kalabalık ortamlarda çok bulunmamaya gayret gösterilmelidir, çünkü kalabalık ortamlar terör örgütlerinin yok etmek istedikleri asıl amaç olmaktadır.

- Kalabalık yerlerde (özellikle terminal, havaalanı, havalimanı, otel işletmeleri vb.) güvenlik personellerinin sayısı fazla olmalıdır. İşinin gerektirdiği beceri ve yeteneklere uygun olmalıdır. Bölgelerde bulunan kameralar fazla olmalı ve her yönden uygun açıya sahip olmalıdır.

- Turist kafilelerine yönelik olarak gerekli sayıda güvenlik personeli ile tur organizasyonları tamamlanabilir.

\section{KAYNAKLAR}

Aksu, M., Aktaş, A.R., Oku, O. ve Şentürk, F.K. (2013). Yabancı turistlerin güvenlik algılarının analizi: Alanya örneği. International Conference on Euroasian Economies 2013, Session 5C Tourism II, 744-754.

Akyurt, H. ve Atay, L. (2009). Destinasyonda İmaj Oluşturma Süreci. Aksaray Üniversitesi İktisadi ve İdari Bilimler Fakültesi Dergisi, 1(1), 1-14.

Alan, E. (2016). Terör-Pkk 40 Ylllık Ihanet. Ankara: Bilgi Yayınevi.

Aymankuy, Ş., Güdü Demirbulat, Ö. ve Aymankuy, Y. (2016). Yerli Turistlerin Güvenlik Algilarının Belirlenmesi - Güneydoğu Anadolu Bölgesi Örneği. International Journal of Human Sciences, 13(1), 965-981. 
Bayhan, İ., ve Ünlüönen, K. (2016). Turist Tercihlerinde Güvenliğe İlişkin Tutumlarının Etkisi: Bir Alan Araştırması. Elektronik Sosyal Bilimler Dergisi, 4.

Caşın, H. M. (2008). Uluslararası Terörizm. (1. Basım). Ankara: Nobel Yayınları.

Çakmakçı, E. (2015). Turizm ve Suç Arasındaki İlişki ve Suçun Önlenmesine Yönelik Teoriler. Turizm Akademik Dergisi, 2(1), 49-59.

Çeken, H. (2016). Terör Olaylarının Turizme Etkisi: Türkiye Üzerine Bir Değerlendirme. (Yüksek Lisans Tezi). Yalova Üniversitesi, Sosyal Bilimler Enstitüsü, Yalova.

Çılgınoğlu, H. (2018). Uluslararası Sağlık Turizminin Ekonomik, Hukuki Ve İdari Yönden Değerlendirilmesi: Türkiye'deki Hastaneler Üzerinde Örnekleme. (Doktora Tezi). Kastamonu Üniversitesi, Sosyal Bilimler Enstitüsü, Kastamonu.

Demirci, Y. (2018). Terörün İstanbul Turizmine Etkileri. (Yüksek Lisans Tezi). İstanbul Ticaret Üniversitesi, Sosyal Bilimler Enstitüsü, İstanbul.

Hacıoğlu, N. ve Saylan, U. (2014). Arap Baharı’nın Turizme Yansımaları: Arap Ülkeleri ve Türkiye. Ballkesir University, The Journal of Social Sciences Institute, 17(32), 55-80.

İstanbul Kalkınma Ajansı. (2012). Türkiye ve İstanbul Bölgesi'nde Turizm. İstanbul.

Kozak, N. (2010). Turizm Pazarlaması. (3. Bask1). Ankara: Detay Yayıncılık.

Köşker, H. (2017). Krizlerin Turizm Sektörüne Etkileri Üzerine Bir Araştırma: 2016 Yılı Türkiye Örneği. Akademik Bakış Dergisi, (62): 216-230.

Küçükaltan, D. (2012). Terörizmin Hedefindeki Sektör: Turizm (Kronolojik Bir Yaklaşım). (1.Bask1). Ankara: Detay Yayıncılık.

Matilda Van Niekerk, A. P. (2015). How do Terrorism and Tourism Co-Exist in Turbulent Time? Researcgate, 3-4.

Murphy, P., Pritchard, M. P. ve Smith, B. (2000). The Destination Product and Its Impact on Traveller Perceptions. Tourism Management, 21(1), 43-52. https :// eurekamag.com /research/003/582/003582450.php. (Erişim Tarihi: 01.04.2019).

Polat, T. (2019). Turizm ve Güvenlik: İstanbul İlinde Bir Uygulama. (Yüksek Lisans Tezi). Balıkesir Üniversitesi, Sosyal Bilimler Enstitüsü, Balıkesir.

Seçilmiş, C. (2005). Turistlerin Ziyaret Ettikleri Yörelerdeki Güvenlik Algllamaları ve Turizmde Güvenlik Eğitimi. (Yüksek Lisans Tezi). Gazi Üniversitesi, Eğitim Bilimleri Enstitüsü. Ankara.

Seçilmiş, C. (2009). Turistlerin Kişisel Değişkenlerinin Güvenlik Algılamalarındaki Rolü. Elektronik Sosyal Bilimler Dergisi, 8(30), 152-166.

Seçilmiş, C. ve Ünlüönen, K. (2009). İstanbul'u Ziyaret Eden Turistlerin Güvenlik Algılamaları Üzerine Bir Araştırma. İşletme Araştırmaları Dergisi, 1(1), 65-84.

Serçek, G. ve Serçek, S. (2016). Turizm Sektörünün Gelişmesi Önündeki Engel: Terörizm. International Journal of Social Science, 42 (3), 431-444.

Şener, Y. (2012). Terör ve Turizm İlişkisi: Türkiye Üzerine Yansımalar. (Yüksek Lisans Tezi). Düzce Üniversitesi, Sosyal Bilimler Enstitüsü, Düzce.

Timothy, D.J. ve Teye, V.B. (2009). Tourism and the Lodging Sector. Oxford: Butterworth-Heinemann.

World Trade Organization (WTO) (2001). $2001 \quad$ Haberleri. https://www.wto.org/english/news_e/news01_e/news01_e.htm. (Erişim Tarihi: 20.03.2019).

Yılmaz, B.S. ve Yılmaz, Ö.D. (2005). Terörizm ve Terörizmin Hedefi Olarak Turizm Endüstrisi. Elektronik Sosyal Bilimler Dergisi, 4(13), 39-58.

\section{Internet Kaynakları}

https://odatv.com/turistler-turkiyeye-gelmeden-once-googleda-ne-ariyor-1306171200.html, Erişim tarihi: 23.02.2020. 
https://www.bbc.com/turkce/haberler-turkiye-38278551, Erişim tarihi: 29.03.2020.

https://tr.sputniknews.com/turkiye/201606281023616914-ataturk-havalimani-patlama-silah-sesi/, Erişim tarihi: 29.03.2020.

https://www.kamupersoneli.net/gundem/istanbul-reina-teror-saldirisini-oven-paylasimlara-sorusturmaacildi-h20234.html, Erişim tarihi: 29.03.2020.

https://www.sabah.com.tr/gundem/2016/03/21/teror-propagandasi-yapan-turist-sinir-disi-edilecek1458598415, Erişim tarihi: 29.03.2020.

http://www.diyarbakirsoz.com/gundem/son-dakika-istanbul-istiklal-caddesi-patlamasinda-olu-veyaralilarin-isimleri-aciklandi-mi-149588, Erişim tarihi: 29.03.2020.

https://www.iha.com.tr/haber-taksimde-patlama-144222/, Erişim Tarihi: 29.03.2020.

https://www.hurriyet.com.tr/gundem/turkiyenin-en-kanli-teror-saldirisi-30282825, Erişim tarihi: 29.03.2020.

https://www.bbc.com/turkce/haberler/2015/01/150106_sultanahmet_bomba, Erişim tarihi: 29.03.2020. 